\title{
The Northern Migrations from a drying Sahara $(6,000$ years BP): cultural and genetic influence in Greeks, Iberians and other Mediterraneans
}

\author{
Antonio Arnaiz-Villena*, Ignacio Juarez, José Palacio-Grüber, \\ Adrián Lopez-Nares, Fabio Suarez-Trujillo \\ Department of Immunology, Universidad Complutense, School of Medicine, Madrid, Spain. \\ * Corresponding author: Antonio Arnaiz-Villena. Departamento de Inmunología, Facultad de Medicina, Universidad \\ Complutense de Madrid. Pabellón 5, planta 4. Avd. Complutense, Plaza Ramón y Cajal, s/n. 28040 Madrid, Spain. \\ E-mail:arnaizville@hotmail.com; aarnaiz@med.ucm.es Web page: http://chopo.pntic.mec.es/biolmol/
}

(Received 24 April 2021; Accepted 10 May 2021; Published 20 May 2021)

\begin{abstract}
Greeks have a Sub-Saharan gene input according to HLA and other autosomic markers. Iberians, Canarians, and North Africans show a close genetic relatedness. This is concordant with a drying humid Sahara Desert, which may have occurred about 6,000 years BC, and the subsequent northwards emigration of Saharan people may have also happened in Pharaonic times. Present study confirms this African gene input in Greeks according to $12^{\text {th }}$ HLA International Workshop data, which was studied some years before by us. This genetic input into Atlantic and Mediterranean Europe/Africa is also supported with Lineal Megalithic Scripts in Canary Islands (as well as in Iberia) together with simple Iberian semi-syllabary rock inscriptions both at Canary Islands and Ti-m Missaou (Algeria, Central southern Sahara). Lineal African/European scripts are found in some language scripts like Berber/Tuareg, Iberian, Runes, Etruscan, Bulgarian (Sitovo and Gradeshnitza, 6,000 years BP), Italian Old Scripts (Lepontic, Venetic, Raetic), Minoan Lineal A, and other Aegean scripts. The possibility that Megalithic Lineal Scripts have given rise to these languages lineal writing is feasible because admixture of languages rock scripts and Megalithic Lineal Scripts may be found. Thus, resistance of Canarian aborigines (Guanches) to Cartago, Rome and Arabs left a bulk of Canarian-Saharan information which is used to study both Saharan and Canarian Prehistory, and also Atlantic and Mediterranean beginning of European and other civilizations: this preserved prehistoric inheritance may be named the "Saharo-Canarian Circle" of prehistoric knowledge. Also, linguisticsepigraphy, physical anthropology ,archaeology and domesticated cattle shows a close North Africa-Iberia Mesolithic/Neolithic relationship and demonstrates that the demic diffusion model does not exist in Iberia. Also, Tassili Sahara paintings of domesticated cattle appear 1,000 years before that agricultural practices started at Middle East.
\end{abstract}

Keywords: Greeks, Macedonians, Sahara, Africa, Iberia, HLA, Genetics, Spaniards, Portuguese, Berbers, Algerians, demic, diffusion, Canary Islands, Lanzarote, Malta, Cart-ruts, Quesera, Cheesboard, Iberian, language, Guanche, Usko-Mediterranean, Phoenicians 


\section{Introduction}

Jean Dausset at $5^{\text {th }}$ HLA Anthropology Workshop (Evian, France 1972) showed that HLA was useful as a very polymorphic autosomic marker for studying origin, relatedness and unrelatedness of human populations (Degos \& Dausset 1974). In a systematic study of Mediterranean populations with HLA-DRB1 alleles, we unexpectedly found that Greek populations behaved as outgroups with respect to other Mediterraneans (Arnaiz-Villena et al. 2001a). Further looking into these results, we found that some Greek HLA-DRB1 alleles were shared with Sub-Saharan populations and not with other Mediterraneans. Greek HLA typing had been done by Greek laboratories in the context of $12^{\text {th }}$ HLA Workshop (Bodmer et al. 1997; Clayton \& Lonjou 1997; Hammond et al. 1997). These published Workshop results were controversial when further analysed (Arnaiz-Villena et al. 2001a; 2002) in spite that other autosomic markers were found to support that Greek gene pool have more in common with Sub-Sahara Africans than other Mediterraneans (Dörk et al. 1998; Padoa et al. 1999). In addition, other independent authors also found that HLA genes in Greeks were shared with Sub-Saharans (Hajjej et al. 2006) and behaved as outgroups of the Mediterranean populations cluster. Finally, these results have lately been ignored in scientific literature and another single publication from a Greek group established that apparently Greek HLA-DRB1 genes were not shared with Sub-Saharans (Papassavas et al. 2000). We have now decided to put up and repeat all analyses and data sources in order to fix the question whether Greeks share or not HLA-DRB1 genes with SubSaharan Africans and whether they behave as an outgroup of other Mediterranean populations or not according to the double-blinded results given by Greek laboratories and their double blinded HLA-DRB1 typing assigned by the Central Analysis laboratories of $12^{\text {th }}$ HLA Workshop (Rennes and Oxford) (Bodmer et al. 1997; Clayton \& Lonjou 1997; Hammond et al. 1997).

In the present paper, we aim to: 1) further analyse the contradictory Greek genetic results in order to definitive clarify the origin of Greek HLA-DRB1 alleles genetic and cultural bases in comparison with Mediterranean and African populations, and 2) summarize ours and others findings that show African genetic relatedness with Iberians since Prehistory, demonstrating that a gene flow existed from Africa to southern Europe 
at different times and that this gene flow could also be bidirectional, i. e.: also from Europe to Africa (Arnaiz-Villena et al. 1999a, 1999b; 2001a, 2001b; 2002).

\section{Material and Methods}

- Sampling

A) Specific HLA-DRB1 allele frequencies of Greeks and Sub-Saharan populations obtained from $12^{\text {th }}$ International Histocompatibility Workshop data (Bodmer et al. 1997; Clayton \& Lonjou 1997; Hammond et al. 1997) were used for our study (Arnaiz-Villena et al. 2001a). Origin of these and other populations is shown in Table 1. Greek samples came from Attika (Bodmer et al. 1997, pages 275, 676, 677, 678; Stavropoulos-Giokas et al. 1997, page 325), Cyprus (Bodmer et al. 1997, pages 275, 676, 677, 678; Stavropoulos-Giokas et al. 1997, page 325), and Aegean Islands (Bodmer et al. 1997, pages 275, 676, 677, 678; Stavropoulos-Giokas et al. 1997, page 325). Total number of Greek individuals was 295 (Attika Greeks: 96; Aegean Greeks: 98; Cypriot Greeks: 101). $12^{\text {th }}$ Workshop Thrace Greeks (Pomaki) were left out from our study (Stavropoulos-Giokas et al. 1997, page 325) because a possible mixed origin. Also, Pontii Greeks (individuals from North Anatolia, Turkey, Greek speakers) were left out because of their uncertain origin.

B) Other HLA-DRB1 Greek allele frequencieswere obtained and published by (Papassavas et al. 2000) from an undetermined Greek origin (see Table 4 and Typing section below). Total number of Greek individuals was 246.

C) Other populations were either HLA-DRB1 typed in our laboratory or taken from other authors publications in order to perform relatedness analyses (Table 1).

- Typing

A) Populations included in the $12^{\text {th }}$ International Histocompatibility Workshop were double-blinded typed in different laboratories and most assigned typing was decided at the Central Workshop Laboratory (Rennes, France). Some participant labs had sampling facilities but not typing facilities, 
and other ones vice versa; 58 laboratories offered samples to other laboratories for typing and 50 laboratories asked for samples to test (see Appendix I, page 31). These $12^{\text {th }}$ HLA Workshop Greek typings were the ones used by us for the present and previous papers (Arnaiz-Villena et al. 2001a); Sub-Saharan HLA typing were also taken from $12^{\text {th }}$ HLA Workshop data (Table 1). Method of HLA Class II typing was SSO-PCR (Stavropoulos-Giokas et al. 1997, page $325)$.

B) Greek individuals sample from (Papassavas et al. 2000), HLA class II typing was carried out as follows (literally taken from this reference; Material and Methods section): “Two hundred forty-six unrelated random healthy individuals originated from different parts of Greece entered the study. The age ranged between 20 and 59 years. The population consisted of 114 and 132 females. Peripheral blood was drawn after informed consent. All individuals were of Greek origin and their parents and grandparents were born in Greece”. HLA high resolution typing was performed by PCR-reverse dot blot method.

C) Other populations analysed in our own laboratory and in others are included in the comparison. Some of them have been re-typed for DRB1 alleles following a PCR-SSOP-Luminex method for the present study. Other laboratory typing protocols have been used in different laboratories (Table 1).

\section{- Statistical analyses}

Phylogenetic trees (dendrograms) were constructed with the allelic frequencies by applying the Neighbour-Joining (NJ) method (Saitou \& Nei 1987), with the genetic distances between populations (Nei 1972) and using DISPAN software containing the programs GNKDST and TREEVIEW (Nei 1973; Nei et al. 1983). A two-dimensional representation was carried out using the VISTA v5.02 computer program (Young \& Bann 1996). Correspondence analysis comprises a geometric technique that may be used for displaying a global view of the relationships among populations according to HLA (or other) allele frequencies. This methodology is based on the allelic frequency 
variance among populations (similarly to classical principal components methodology) and on the display of a statistical projection of the differences.

Table 1. Populations used for comparisons performed in the present work. $\mathrm{N}=$ number of individuals analysed for each population. See the references Bodmer et al. 1997; Clayton \& Lonjou 1997; Hammond et al. 1997.

\begin{tabular}{|c|c|c|c|}
\hline & Region and population & $\mathbf{n}$ & Reference \\
\hline 1 & Macedonians & 172 & Arnaiz-Villena et al. 2001a \\
\hline 2 & Moroccans & 98 & Gomez-Casado et al. 2000 \\
\hline 3 & Berbers (Souss) & 98 & Izaabel et al. 1998 \\
\hline 4 & Moroccan Jews & 94 & Roitberg-Tambur et al. 1995 \\
\hline 5 & Spaniards & 176 & Martinez-Laso et al. 1995 \\
\hline 6 & Spanish Basques & 80 & Martinez-Laso et al. 1995 \\
\hline 7 & French & 179 & Imanishi et al. 1992 \\
\hline 8 & Algerians & 102 & Arnaiz-Villena et al. 1995 \\
\hline 9 & Sardinians & 91 & Imanishi et al. 1992 \\
\hline 10 & Italians & 184 & Imanishi et al. 1992 \\
\hline 11 & Jews Ashkenazi & 80 & Martinez-Laso et al. 1996 \\
\hline 12 & Jews Non-Ashkenazi & 80 & Martinez-Laso et al. 1996 \\
\hline 13 & Cretans & 135 & Arnaiz-Villena et al. 1999a \\
\hline 14 & Greeks (Attika) & 96 & $\begin{array}{c}\text { Clayton \& Lonjou } 1997 \\
\left(12^{\text {th }} \text { HLA Workshop }\right)\end{array}$ \\
\hline 15 & Greeks (Aegean) & 98 & $\begin{array}{c}\text { Clayton \& Lonjou } 1997 \\
\left(12^{\text {th }} \text { HLA Workshop }\right)\end{array}$ \\
\hline 16 & Greeks (Cyprus) & 101 & $\begin{array}{c}\text { Clayton \& Lonjou } 1997 \\
\left(12^{\text {th }} \text { HLA Workshop }\right)\end{array}$ \\
\hline 17 & Lebanese (NS) & 59 & $\begin{array}{l}\text { Clayton \& Lonjou } 1997 \\
\left(12^{\text {th }} \text { HLA Workshop) }\right.\end{array}$ \\
\hline 18 & Lebanese (KZ) & 93 & $\begin{array}{l}\text { Clayton \& Lonjou } 1997 \\
\left(12^{\text {th }} \text { HLA Workshop }\right)\end{array}$ \\
\hline 19 & Oromo & 83 & $\begin{array}{l}\text { Clayton \& Lonjou } 1997 \\
\left(12^{\text {th }} \text { HLA Workshop }\right)\end{array}$ \\
\hline 20 & Amhara & 98 & $\begin{array}{l}\text { Clayton \& Lonjou } 1997 \\
\left(12^{\text {th }} \text { HLA Workshop }\right)\end{array}$ \\
\hline 21 & Fulani & 38 & $\begin{array}{l}\text { Clayton \& Lonjou } 1997 \\
\left(12^{\text {th }} \text { HLA Workshop }\right)\end{array}$ \\
\hline 22 & Rimaibe & 39 & $\begin{array}{l}\text { Clayton \& Lonjou } 1997 \\
\left(12^{\text {th }} \text { HLA Workshop) }\right.\end{array}$ \\
\hline 23 & Mossi & 42 & $\begin{array}{l}\text { Clayton \& Lonjou } 1997 \\
\left(12^{\text {th }} \text { HLA Workshop) }\right.\end{array}$ \\
\hline 24 & San (Bushmen) & 77 & Imanishi et al. 1992 \\
\hline 25 & Senegalese & 192 & Imanishi et al. 1992 \\
\hline
\end{tabular}




\section{Results}

\section{Greeks and presently Sub-Saharan African genes}

In order to clarify the possible origin of the $12^{\text {th }}$ HLA Workshop Greek populations, which appeared as outgroups in both Neighbour-Joining and correspondence analysis, (results not shown; see Arnaiz-Villena et al. 1999a; Gomez-Casado et al. 2000), HLADRB1 alleles were only studied in Greeks and also searched for in other nearby populations including. Some of these alleles were found mostly in Sub-Saharan populations and sporadically in non-Mediterranean populations around the world (Dos Santos et al. 2016). The populations in which the highest frequencies of these alleles have been found are mostly from Ethiopia (Amhara and Oromo) and West Africa (Mossi, Fulani and Rimaibe) (see Discussion, Table 2). Then, they were included in the Mediterranean relatedness analysis: Greeks still behave as an out-group and cluster with the above mentioned Sub-Saharan groups (Figs. 1 and 2).

The Neighbour-Joining phylogenetic tree generated, as well as the correspondence analysis performed support this genetic relationship (Figs. 1 and 2). These groupings are observed between all the Greek populations included in our study with the $12^{\text {th }}$ International Workshop data and the Sub-Saharans (data taken from the same $12^{\text {th }}$ HLA Workshop, see Table 1). Other Mediterranean populations, geographically close to Greece, are genetically placed more distant (Figs. 1 and 2). There is no close relationship between the Greeks and the Senegalese/South African blacks or the Bushmen (San) (Fig. 2) (Bantu expansion, McEvedy \& Jones 1978). Close long tree branches do not mean relatedness between branches but that they are very different to each other and are outgroups far from other dendrogram populations (Fig. 1); Figure 2 places Senegalese and San-Bushmen as out-groups. 


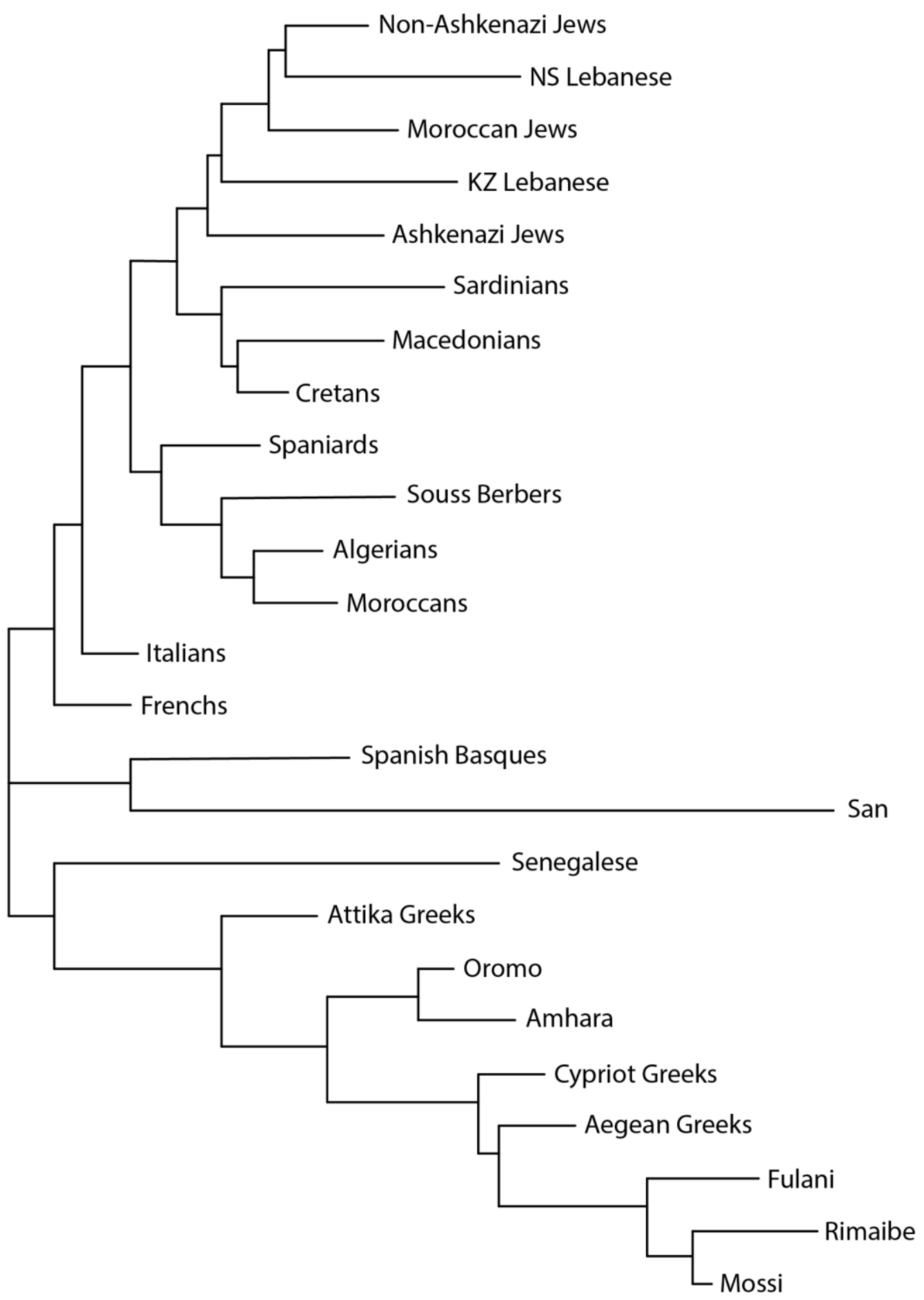

Fig. 1 Dendrogram performed with Neighbour-Joining method showing genetic relatedness between Attika, Aegean and Cyprus Greeks and other Mediterranean and Sub-Saharan populations.

Genetic distances between populations were calculated with GNKDST software using high-resolution HLA-DRB1 frequencies (Bodmer et al., 1997, pages 676, 677, 678; Clayton \& Lonjou 1997; Hammond et al. 1997; Bootstrap test showed values of 100 in all of the nodes after 1000 replicates. 


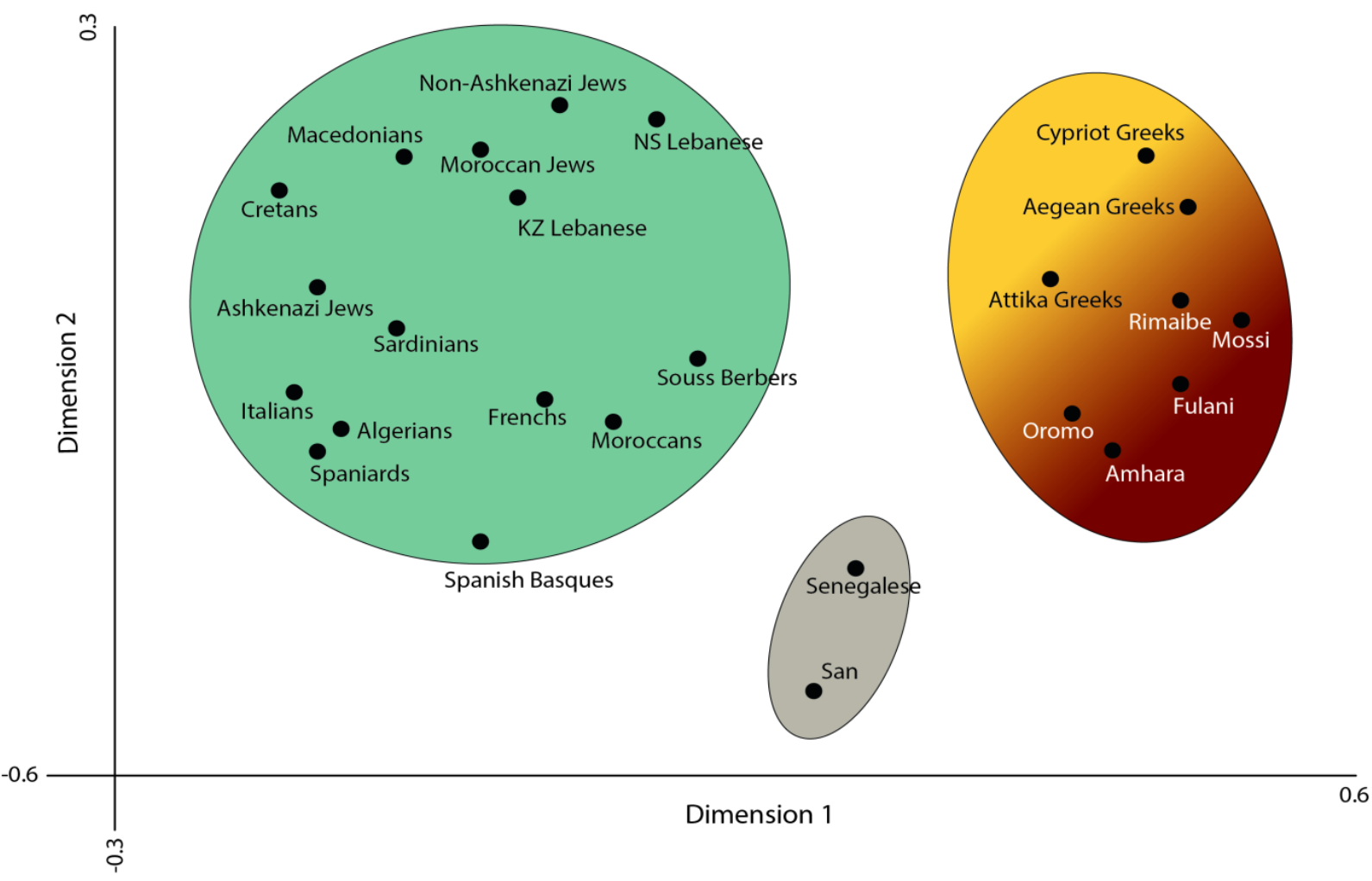

Fig. 2. Correspondence analysis showing a global view of the relationship between Greeks and other Mediterranean and Sub-Saharan populations.

The analysis was performed using HLA-DRB1 high-resolution frequencies. 


\section{Discussion}

There is no doubt that North Africa and Southern Europe gene flow has occurred since Prehistory, probably in both directions. However, Sahara extreme changes to desert, which started about 6,000 years BC, suggest that South to North gene (people) flow was more important. This has brought cultural and anthropological consequences. Genetically, a Iberians and Maghreb inhabitants close relationship is found by several different groups with different methodology (Arnaiz-Villena et al. 1999a; 1999b; 2002; Currat et al. 2010; Botigue et al. 2013; González-Fortes et al. 2019). Genetic differences between Western Mediterraneans and North West Africans and Canary Islanders are very scanty (Arnaiz-Villena et al. 2015; 2017; Hajjej et al. 2018); these latter groups of people belong to a very related cultural, genetic and geographic population (Arnaiz-Villena et al. 2001b; 2001c; 2001d; 2002; 2015; 2017; 2019a; Medina \& Arnaiz-Villena 2018a; 2018b). In addition, a strong very old (probably Megalithic) culture and thus genetic Atlantic relationships are established among Western Africa, Europe and Canary Islands (Arnaiz-Villena et al. 2018; 2019a; Medina \& Arnaiz-Villena 2018a; 2018b). In contrast, Eastern-North Africa, Saharan migrations and European relationships are less studied (Arnaiz-Villena et al. 1999b; 2001a; 2002) but they obviously existed. In that context, Greek and Sub-Saharan populations genetic relationships must be interpreted. Europe and Greece immigration from Africa has occurred since Prehistory (see above), but also during Egyptian pharaonic times a Black dynasty with their followers were expelled ad established in Greece. Indeed, ancient Greeks believed that their religion and culture came from Egypt (Bernal 1987; Herodotus 1989). Also, Herodotus (Herodotus 1989) states that the daughters of Danaus (who were black) came from Egypt in great numbers to settle in Greece.

Western Europe and North Africans: Genetics, Archaeology and physical Anthropology

Several studies (Degos \& Dausset 1974; Cambon-Mouzon et al. 1982) and our own previous research (Rodríguez-Córdoba et al. 1981; Arnaiz-Villena et al. 1981; Regueiro \& Arnaiz-Villena 1988) have pointed out that the HLA-A30-B18-DR3-BF*F,1 haplotype was a marker for Basques, Sardinians and Spaniards. Its frequency in other 
populations was significantly lower, except for Mediterranean North Africans; this suggested a paleo-North African/Iberian origin for part of the Basque gene pool (Arnaiz-Villena et al. 1981). Also, complete HLA data on Basques and Spaniards (Martínez-Laso et al. 1995) have been analysed by DNA indirect sequencing and compared with data from North African populations (Algerians) with at least $70 \%$ Berber component (Julien 1951; Benmamar et al. 1993; Rachid 1994; Arnaiz-Villena et al. 1995).

Skeletal studies from Mesolithic and Neolithic Iberian samples have been extensively carried out by Meiklejohn et al. (1984), Lubell et al. (1994), Lalueza-Fox (1996), and Jackes et al. (1997a). Jackes et al. (1997a) analysed the agricultural transition by using dental and skeletal variables obtained from partial data. They performed an exhaustive analysis of their own and other data on Mesolithic and Neolithic Iberian skeletal parameters. A scatter plot of 8 craniometric variables from 20 skeletons from Iberia (Spain: Majorca, Tarragona, Basque Country, Catalonia, Cantabria, Barcelona, Burgos, Castilla, Andalusia, Granada; Portugal: Eira, Pedrinha, Escoural, Melides, Cabezo da Aruda, Moita de Sehastiago) showed that there was no significant change in the studied variables between Neolithic and Mesolithic samples. Both, Lalueza-Fox (1996) and Jackes et al. (1997a, 1997b) agreed that stature is similar in Neolithic and Mesolithic Iberian skeletons. Dental caries rates do not show a discontinuity either, and the observed reduction rate in the Neolithic shows complex dietary changes that started during the Mesolithic and continued into the Neolithic (Lubell et al. 1994). Thus, the demic diffusion model put forward by Cavalli-Sforza et al. 1994, which implies an important (or complete) replacement of the population, is not sustainable for Iberia, where no revolutionary way of life changes or physical anthropometry and diet differences were found.

In conclusion, the demic diffusion model hypothesizes that Neolithic farmers who were coming from the Middle East were slowly reaching Mesolithic Western Europe DOES NOT HOLD (Cavalli-Sforza 1996). First, there is no evidence of Neolithic replacement of people on the Iberian Peninsula. On the contrary, the suggested conformity of Iberian craniometric data to a demic diffusion model simply does not exist (Cavalli-Sforza 1976); Mesolithic and Neolithic bones show clear continuity (Jackes et al 1997b). Second, genetic data in North Africans, Spaniards, Basques, Portuguese and Cretans (Arnaiz-Villena et al. 1981; 1997; 1999b; Corte-Real et al. 1996; Izaabel et al 1998) support substantial gene flow from paleo-North African 
populations to Iberia. Also, common extended HLA haplotypes between present day North African and Iberian populations, including Basques, exist (Arnaiz-Villena et al. 1997; Izaabel et al. 1998). Third, archaeological studies at the mouth of the Guadalquivir River (La Marismilla, Sevilla) (Escacena-Carrasco 1996) showed that domesticated bovines and cats came with people from Africa about 5,000 years ago; in addition, the predynastic Egyptian El-Badari culture (4,500 years ago) is similar to many southern Iberian Neolithic settlements in pottery and animal domestication (Escacena-Carrasco 1996). Cardial impressed pottery is common and contemporary in Western Europe and North African coasts. The coastal distribution of cardial impressed pottery in Western Mediterranean Europe (Lewthwaite 1986) and across the Maghreb (Gilman 1992; Lubell et al. 1992) provides good evidence of circum-Mediterranean contacts by sea. Both El-Badari and Iberian Neolithic people probably came from the drying Sahara area, forced to migrate since about 6,000 years BC (McCauley et al. 1982; Chandan \& Peltier 2020). Indeed, Tassili cave paintings in the Middle of the Sahara Desert (south-eastern Algeria) show domesticated bovine about 1,000 years before documented Neolithic agricultural practices starting in the Middle East (CavalliSforza 1996), and Sahara also contains Iberian lineal semi-sillabary writing lineal characters (Arnaiz-Villena et al. 2021). Fourth, the Iberian language has been transcripted and translation proposals put forward and have been found to be similar to Etruscan and Minoan Linear A (Arnaiz-Villena \& Alonso García 1998; 1999; 2008; 2009). Basque (and its Spanish translation) has been the Rosseta stone. In fact, Basque and Old Iberian language numerals are almost identical (Orduña-Aznar 2005; 2013; Ferrer i Jane 2009). The Basque language had also been related to North Caucasian and to Etruscan languages (Bengston 1991; Ruhlen 1991; Cavalli-Sforza et al. 1994; Arnaiz-Villena \& Alonso-Garcia 2008; Arnaiz-Villena \& Alonso-García 2009). Thus, the question that Jared Diamond posed to Terrell et al. 1998 - Do Terrell et al. believe all Europeans spoke a single tongue, Basque, until a few thousand years ago? - can be answered. The answer is: it is possible. Caucasians, Etruscans, and the first Minoans from Crete spoke a language similar to Basque and Berber; probably, the origin of this language came from the Saharan people who were forced to migrate northward in preNeolithic times when desiccation started (McCauley et al. 1982). Finally, it is noteworthy that Canary Islands aborigines or Guanches long survived invasions from Cartago, Rome and Arabs before Europeans defeated them (Arnaiz-Villena \& AlonsoGarcía 2001). 
Table 2. Quasi specific HLA-DRB1 alleles found in Greeks in common with SubSaharan populations. AF: allele frequency.

\begin{tabular}{|l|c|c|c|c|c|c|c|c|}
\hline Allele & \multicolumn{3}{|c|}{ Greeks AF (\%) } & \multicolumn{2}{c|}{ West Africans AF (\%) } & \multicolumn{2}{c|}{ Ethiopia AF (\%) } \\
\hline DRB1 & Attika & AegeanIslands & Cyprus & Mossi & Fulani & Rimaibe & Amhara & Oromo \\
\hline $\mathbf{0 3 : 0 5}$ & & 2.5 & & 0.8 & 0.2 & 0.8 & & \\
\hline $\mathbf{0 3 : 0 7}$ & & 2.2 & 3.2 & 0.8 & 0.2 & 0.8 & 2.1 & \\
\hline $\mathbf{0 4 : 1 1}$ & & & 0.4 & & 0.6 & & & \\
\hline $\mathbf{0 4 : 1 3}$ & 0.5 & 0.6 & 0.9 & & & & 0.6 & 0.6 \\
\hline $\mathbf{0 4 : 1 6}$ & & 0.6 & 0.9 & & & & 0.6 & 0.6 \\
\hline $\mathbf{0 4 : 1 7}$ & & & 0.4 & & 0.6 & & & \\
\hline $\mathbf{0 4 : 2 0}$ & 0.1 & & 0.4 & & 0.6 & & 0.6 & 0.6 \\
\hline $\mathbf{1 1 : 1 0}$ & & 2.9 & 1.9 & & & 0.3 & & 0.2 \\
\hline $\mathbf{1 1 : 1 2}$ & & 2.9 & 1.9 & & & 0.3 & 0.4 & 0.2 \\
\hline $\mathbf{1 3 : 0 4}$ & & & 0.9 & 0.7 & 1.4 & 1.1 & & \\
\hline $\mathbf{1 3 : 1 0}$ & & & 0.2 & 0.8 & 0.2 & 0.8 & & \\
\hline
\end{tabular}

\section{Greeks and Sub-Saharans}

Mediterranean Area was a densely populated region between Sahara Desert and European Ices by thousands of years after 10,000 years BC (Arnaiz-Villena et al. 1999b; 2002). This "Mediterranean" people (broad cultural sense) comprised a World stretch from Atlantic British and Canary Islands, Western Europe and Africa to North India, including Caucasus, big Persia and Egypt. A very important cultural input was most probably given by displaced Saharans (Fig. 3) to starting all Mediterranean Area civilizations. Thus, the "Classical Mediterranean Culture" was originated by Saharans, Atlantic Western Europeans, and Africans, Central and East Mediterraneans. It cannot be attributed only to Greece and Rome in the view of past and present scientific advances. In the case of Greece, it was unexpectedly found genetic relatedness with Sub-Saharans (Arnaiz-Villena et al. 2001a; Hajjej et al. 2006; Dörk et al. 1998; Padoa et al. 1999) which is not that odd taking into account cultural, genetic, physical anthropology and genetic relationship of Sub-Saharans/North Africans with Iberia and other Europeans. Table 2 shows Greek alleles in common with Sub-Saharans. 
Table 3. Greek HLA-DRB1 allele frequencies taken from the data shown in $12^{\text {th }}$ International Histocompatibility Workshop $(\mathrm{n}=295)$

(Bodmer et al. 1997, pages 676, 677, 678; Clayton \& Lonjou, 1997; Hammond et al. 1997). Alleles with Sub-Saharan origin are remarked in orange and specifically shown in Table 2.

\begin{tabular}{|c|c|c|c|}
\hline Allele & F $(\%)$ & Allele & $\mathbf{F}(\%)$ \\
\hline DRB1*01:01 & 9,5 & DRB1*11:04 & 15,4 \\
\hline DRB1*01:02 & 2,5 & DRB1*11:06 & 1 \\
\hline DRB1*01:04 & 4,9 & DRB1*11:08 & 3,6 \\
\hline DRB1*03:01 & 11,8 & DRB1*11:10 & 4,8 \\
\hline DRB1*03:04 & 0,5 & DRB1*11:12 & 4,8 \\
\hline DRB1*03:05 & 2,5 & DRB1*11:G2 & 4,8 \\
\hline DRB1*03:07 & 5,4 & DRB1*11:18 & 0,5 \\
\hline DRB1*04:01 & 3,2 & DRB1*11:22 & 0,3 \\
\hline DRB1*04:02 & 3,2 & DRB1*11:25 & 23,3 \\
\hline DRB1*04:03 & 1,1 & DRB1*12:01 & 4,9 \\
\hline DRB1*04G1 & 0,9 & DRB1*13:01 & 5,3 \\
\hline DRB1*04:05 & 1,1 & DRB1*13:02 & 9,6 \\
\hline DRB1*04:07 & 0,5 & DRB1*13:03 & 4,1 \\
\hline DRB1*04:08 & 0,5 & DRB1*13:04 & 0,9 \\
\hline DRB1*04:09 & 1,5 & DRB1*13:05 & 0,5 \\
\hline DRB1*04:11 & 0,4 & DRB1*13:10 & 0,2 \\
\hline DRB1*04:13 & 2 & DRB1*13:27 & 5,3 \\
\hline DRB1*04:15 & 0,3 & DRB1*14:01 & 8,1 \\
\hline DRB1*04:16 & 1,5 & DRB1*14:04 & 1 \\
\hline DRB1*04:17 & 0,4 & DRB1*14:07 & 3,4 \\
\hline DRB1*04:20 & 0,5 & DRB1*14:15 & 0,2 \\
\hline DRB1*07:01 & 19,5 & DRB1*15:01 & 8,4 \\
\hline DRB1*08:01 & 1,7 & DRB1*15:02 & 4,7 \\
\hline DRB1*08:03 & 0,4 & DRB1*15:06 & 2,5 \\
\hline DRB1*08:04 & 0,2 & DRB1*16:01 & 12,5 \\
\hline DRB1*08:05 & 1,7 & DRB1*16:02 & 2,2 \\
\hline DRB1*09:01 & 0,9 & DRB1*16:04 & 9 \\
\hline DRB1*10:01 & 9,8 & DRB1*16:08 & 4,6 \\
\hline DRB1*11:G1 & 9,1 & DRB1*NULL & 3,6 \\
\hline DRB1*11:02 & 1 & & \\
\hline
\end{tabular}


Table 3 shows which Greek HLA-DRB1 alleles were found to be shared and relatively frequent with Greeks; this work was double-blinded performed by several World laboratories I the frame of participants in the $12^{\text {th }}$ International HLA Workshop (See Material and Methods section above; Bodmer et al. 1997; Cayton et al. 1997; Hammond et al. 1997).

Therefore, it is a solid finding. Curiously, Papassavas et al. (2000) (Table 4) did not find any of these Greek/African shared alleles with fewer number of Greek individuals of unknown specific origin, 153 less than in $12^{\text {th }}$ HLA Workshop. If they belong to the Workshop work (they are coincidental in time and main authors; see Stavropoulos-Giokas et al. 1997, page 325). Thus, a number of Greek samples sent to $12^{\text {th }}$ Workshop ( $n=295$, Table $3 v s . n=246$, Table 4 ) might have been left out by many reasons or be altogether different in Papassavas et al. (2000) with Greeks of undetermined origin. In any case, we still put forward that Greeks/Africans genetics is shared (Arnaiz-Villena et al. 2001a; Hajjej et al. 2006; Dörk et al. 1998; Padoa et al. 1999) and stick to $12^{\text {th }}$ Workshop results regarding to HLA. This Greek/African genetic sharing is not unusual in the more extensive studies done in Iberia, Canary and other Atlantic Islands and North Africans (Arnaiz-Villena et al. 2017; 2019b; Hajjej et al. 2018). 
Table 4. HLA-DRB1 frequencies found in Greek populations as shown in Papassavas et al. (2000) $(\mathrm{n}=246)$.

It is striking the lack of all Sub-Saharan alleles that have been found in Greeks at the $12^{\text {th }}$ International HLA Workshop (see Table 3).

\begin{tabular}{|c|c|c|c|}
\hline Allele & F $(\%)$ & Allele & $\mathbf{F}(\%)$ \\
\hline DRB1*01:01 & 11 & DRB1*11:02 & 2 \\
\hline DRB1*01:02 & 3,7 & DRB1*11:04 & 34,1 \\
\hline DRB1*03:01 & 12,6 & DRB1*12:01 & 1,6 \\
\hline DRB1*04:01 & 2 & DRB1*12:03 & 0,4 \\
\hline DRB1*04:02 & 3,7 & DRB1*13:01 & 8,5 \\
\hline DRB1*04:03 & 5,7 & DRB1*13:02 & 6,1 \\
\hline DRB1*04:04 & 0,4 & DRB1*13:03 & 2,8 \\
\hline DRB1*04:05 & 5,3 & DRB1*13:05 & 0,4 \\
\hline DRB1*04:07 & 0,8 & DRB1*14:01 & 8,1 \\
\hline DRB1*04:13 & 0,4 & DRB1*14:04 & 0,4 \\
\hline DRB1*07 & 13,4 & DRB1*14:10 & 0,4 \\
\hline DRB1*08:02 & 0,8 & DRB1*15:01 & 11,4 \\
\hline DRB1*08:03 & 0,4 & DRB1*15:02 & 4,9 \\
\hline DRB1*08:04 & 0,4 & DRB1*15:03 & 0,4 \\
\hline DRB1*08:05 & 0,4 & DRB1*16:01 & 22,4 \\
\hline DRB1*09:01 & 1,2 & DRB1*16:02 & 3,7 \\
\hline DRB1*10:01 & 2,4 & DRB1*16:05 & 0,4 \\
\hline DRB1*11:01 & 15,9 & & \\
\hline
\end{tabular}



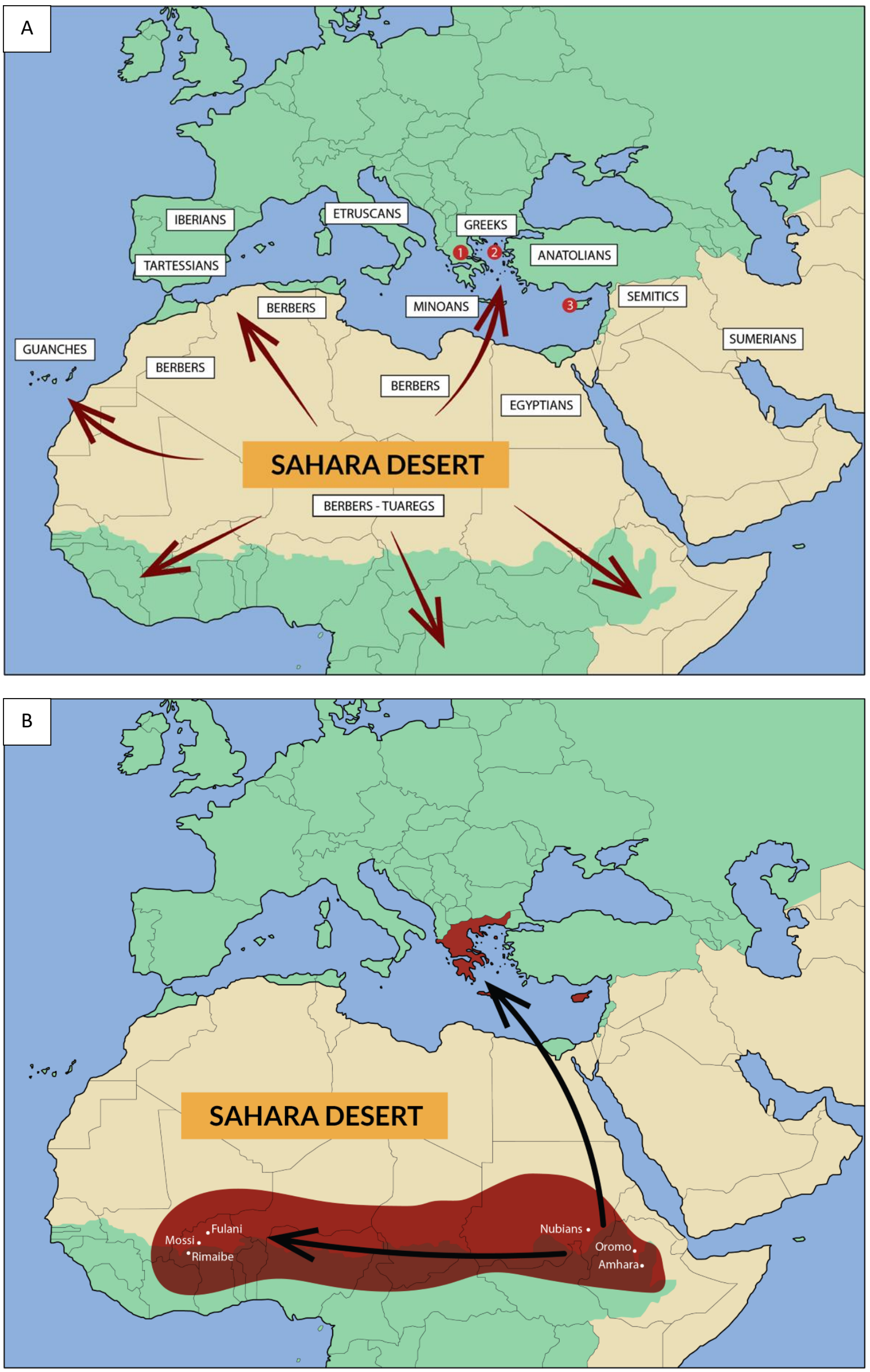
Fig. 3 (A). Mediterranean area showing classic populations (squares).

Arrows represent population movements before 3,000 years B. C. (Sellier \& Sellier 1993). Etruscans have their highest development in the first millennium B.C.; however, their culture was a continuity of a more ancient "Villanovan" (Villanova, Bologna) and pre-Villanovan cultures ( $2^{\text {nd }}$ millennium B.C.) (Elvira 1988). Semitic people were nomadic people, comprising Jews, Arabs, and Phoenicians. Further details can be seen in references (Martinez-Laso et al. 1996; Gomez-Casado et al. 2000; Arnaiz-Villena et al. 1997; 1999a; 2001a; 2001b; 2001c; 2002). In the map: 1) Attika Region, continental Greece territory; 2) Aegean Greek Islands; 3) Geek Cyprus part.

Fig. 3 (B). Map showing postulated migrations of Sub-Saharan populations. Arrows show postulated migrations from Ethiopia to both West Africa and Greece, the latter probably occurring in pharaonic times, to give rise to other Sub-Saharan populations (Fulani, Mossi, Rimaibe; Burkina Faso) and Greeks. Humid Sahara Desert harboured people density before around 6,000 - 5,000 years BC (Chandan \& Peltier 2020).

\section{Conclusions}

1) Saharan and North African peoples emigrated to North when Sahara started to become dry about 6,000 years BC or before.

2) They probably influenced many of the primitive Mediterranean Cultures from Atlantic British and Canary Islands to Persia and North India, including Greeks and Iberians.

3) The appearance of ancient linear writings i.e.: Berber/Tuareg, Iberian, Etruscan, Minoan, Runes, and other linear scripts may have a common Saharan origin.

4) Agricultural/domestic breeding demic diffusion model from Middle East to Iberia (West Europe) does not exist: physical anthropology (skeletons and teeth studies, genetics, writing and languages. Most likely these technologies were locally acquired among Sahara, Iberia and North Africa, both Mediterranean and Atlantic: in fact domesticated animal rock paintings exist in Sahara 1,000 years before than these technologies are reported in Middle East.

5) Genetics in Iberia is difficult to separate from North Africa and Prehistoric gene flow is postulated.

6) Genetics in Greeks have also shown similarities with Sub-Saharans and it is also possible that admixture occurred because of the Sahara desertification, migrations and/or fights in Egypt within different ethnic groups (i. e.: Danao's Daughters). 
7) Iberian/Basque equivalences and discoveries of Iberian scripts in Canary Islands and Sahara (Ti-m Missaou, Hoggar area. Algeria) may be a starting of Lineal/Mediterranean writings evolving from Lineal Megalithic scripts. Those findings are crucial and may be important for understanding main Atlantic/Mediterranean cultures in the context of the "Saharo-Canarian Circle".

\section{Aknowledgements}

We thank University Complutense of Madrid for its continuous support. PI18/00721 grant is hold from Ministerio de Ciencia, Innovación y Universidades and FEDER funds.

Conflict of interests: The authors declare no conflict of interest

\section{References}

Arnaiz-Villena A. \& Alonso-García J. (1st edition) 1998. El Origen de los Vascos y otros Pueblos Mediterráneos (2a edición). Madrid, Spain: Editorial Complutense. | New Edición 2011. Madrid, Spain: Ed. Visión Libros.

Arnaiz-Villena A. \& Alonso-García J. 1999. Minoicos, cretenses y vascos: un estudio genético y lingüístico. Madrid, Spain: Editorial Complutense. Amazon:

https://www.amazon.es/Minoicos-cretenses-vascos-Estudios-

Complutenses/dp/8489784663

Arnaiz-Villena A. \& Alonso-García J. 2001. Egipcios, Bereberes, Guanches y Vascos. Madrid, Spain: Ed. Visión Libros. (3rd Edition 2011). Amazon:

https://www.amazon.es/Egipcios-Bereberes-Guanches-Vascos-

Lenguas/dp/841726700X ; Wikimedia Commons:

https://commons.wikimedia.org/wiki/File:Iberian-Guanche_inscriptions.pdf

Arnaiz-Villena A. \& Alonso-Garcia J. 2008. Diccionario Etrusco-Euskera-Castellano. Madrid, Spain: Ed. Vision Libros. Amazon: https://www.amazon.es/Diccionarioetrusco-euskera-castellano-Diccionarios-Bilingües-Arnáiz-Villena/dp/8490119368

Arnaiz-Villena A. \& Alonso-Garcia J. 2009. Caucasicos, Turcos, Mesopotamicos y Vascos. Madrid, Spain: Ed. Complutense. Amazon:

https://www.amazon.es/Cauc\%C3\%A1sicos-turcos-mesopot\%C3\%A1micos-vascosHistoria/dp/8417117628

Arnaiz-Villena A, Rodriguez de Córdoba S, Vela F, Pascual J.C, Cerveró J, Bootello A. 1981. HLA antigens in a sample of the Spanish population: common features among Spaniards, Basques, and Sardinians. Hum Genet. 58(3): 344-8. 
Arnaiz-Villena A, Benmamar D, Alvarez M, Diaz-Campos N, Varela P, Gomez-Casado E, Martinez-Laso J. 1995. HLA allele and haplotype frequencies in Algerians. Relatedness to Spaniards and Basques. Hum Immunol. 43(4): 259-68.

Arnaiz-Villena A, Martínez-Laso J, Gómez-Casado E, Diaz-Campos N, Santos P, Martinho A, Breda-Coimbra H. 1997. Relatedness among Basques, Portuguese, Spaniards, and Algerians studied by HLA allelic frequencies and haplotypes. Immunogenetics 47: 37-43.

Arnaiz-Villena A, Iliakis P, González-Hevilla M, Logás J, Gómez-Casado E, Syfidaki K, ...Martínez-Laso J. 1999a. The origin of Cretan population as determined by characterization of HLA alleles. Tissue Antigens 53: 213-26.

Arnaiz-Villena A., Martinez-Laso J., Alonso-García J. 1999b. Iberia: Population Genetics, Anthropology and Linguistics. Human Biology 71: 725-743.

Arnaiz-Villena A, Dimitroski K, Pacho A, Moscoso J, Gómez-Casado E, SilveraRedondo C, ...Martínez-Laso J. 2001a. HLA alleles in Macedonians and the SubSaharan origin of the Greeks. Tissue Antigens 57: 118-127.

Arnaiz-Villena A, Karin M, Bendikuze N, Gómez-Casado E, Moscoso J, Silvera C, ...Martinez-Laso J. 2001b. HLA alleles and haplotypes in the Turkish population: relatedness to Kurds, Armenians and other Mediterraneans. Tissue Antigens 57: 118127.

Arnaiz-Villena A., Martinez-Laso J., Alonso-Garcia J. 2001c. The correlation between languages and genes: the Usko-Mediterranean peoples. Human Immunology 62: 10511061.

Arnaiz-Villena A., Elaiwa N., Silvera C., Rostom A., Moscoso J., Gomez-Casado E., ...Martinez-Laso J. 2001d. The origin of Palestinians and their genetic relatedness with other Mediterraneans. Hum Immunol 62: 889.

Arnaiz-Villena A., Gomez-Casado E., Martinez-Laso J. 2002. Population genetic relationships between Mediterranean populations determined by HLA allele distribution and historic perspective. Tissue Antigens 60: 111-121.

Arnaiz-Villena A., Muñiz E., Campos C., Gómez-Casado E., Tomasi S., Martínez Quiles N., ...Palacio-Gruber J. 2015. Origin of Ancient Canary Islanders (Guanches): presence of Atlantic/Iberian HLA and Y chromosome genes and Ancient Iberian language. Int. J. Mod. Anthrop. 8: 67-93.

Arnaiz-Villena A., Carballo A., Juarez I., Muñiz E., Campos C., Tejedor B., ...PalacioGruber J. 2017. HLA Genes in Atlantic Celtic populations: Are Celts Iberians? Int. J. Mod. Anthrop. 10: 50 - 72.

Arnaiz-Villena A., Medina M., Palacio-Gruber J., Lopez-Nares A., Ruiz-Del-Valle V. 2018. Malta and Lanzarote (Canary Islands, Spain) Cart-ruts and Rock Prehistoric Calendar at Zonzamas, Lanzarote-"Quesera"/Cheeseboard. Int. J. Mod. Anthrop. 11: 214-231. 
Arnaiz-Villena A., Medina M., Lopez-Nares A., Rodriguez-Rodriguez J., Ruiz-DelValle V. 2019a. Cart-ruts in Lanzarote (Canary Islands, Spain) and Malta: first evidence of dating supported by dated ceramics. Int. J. Mod. Anthrop. 2: 115-140.

Arnaiz-Villena A., Lopez-Nares A., Juárez I., Ruiz-Del-Valle V., Callado A., H-Sevilla A., Gomez-Casado E. 2019b. "Latín" rock scripts in Canary Islands are ancient Iberian inscriptions (Iberian-Guanche). A story of forgotten genetics, scripts, pyramids and other prehistoric artifacts. Int. J. Mod. Anthrop. 12: 189 - 212.

Arnaiz-Villena A., Ruiz-del-Valle V., López-Nares A., Suárez-Trujillo F. 2021. Iberian inscriptions in Sahara Desert rocks (Ti-m Missaou, Ahaggar Mts. area, Algeria) and first evidence of incise Iberian rock scripts in continental North Africa.

Int. J. Mod. Anthrop. 2(15): 440-467.

Bengston J.D. 1991. Dene-Sino-Caucasian. In: Proto-Languages and Proto-Cultures; V. Shevoroshkin, ed. Bochum, Germany: Brockmeyer, 42-46.

Benmamar D, Martinez-Laso J, Varela P, Bekhoucha F, Morales P, Arnaiz-Villena A. 1993. Evolutionary relationships of HLA-DR8 alleles and description of a new subtype (DRB1*0806) in the Algerian population. Hum Immunol 36(3):172-8.

Bernal M. 1987. Black Athena: the Afroasiatic roots of classical civilization. London, UK: Free association books, Rutger University Press.

Bodmer J.G., Cambon-Thomsen A., Hors J., Piazza A., Sanchez-Mazas A. 1997. Anthropology report.Introduction. In: Charron D, ed. Genetic diversity of HLA. Functional and medical implications. Vol 1. Paris: EDK, 345- 52.

https://www.amazon.fr/HLA-Genetic-Diversity-Functional-

Implications/dp/2842540034

Botigue L.R., Henn B.M., Grave 1S., Maples B.K., Gignoux C.R., Corona E., ... Bustamante C.D. 2013. Gene flow from North Africa contributes to differential human genetic diversity in southern Europe. Proceedings of the National Academy of Sciences 110 (29): 11791-6.

Cambon-Mouzon A, Ohayon E, Hauptmann G, Sevin A, Abbal M, Sommer E, ... Ducos J. 1982. HLA-A, B, C, DR antigens, Bf, C4 and glyoxalase I (GLO) polymorphisms in French Basques with insulin-dependent diabetes mellitus (IDDM). Tissue Antigens 19 (5): 366-79.

Cavalli-Sforza L.L, Menozzi P., Piazza A. 1994. The history and geography of human genes.New Jersey, USA: Princeton University Press.

Cavalli-Sforza L.L. 1996. Geni, popoli e lingue.Milan, Italy: Adelphi Edizione.

Chandan D., Peltier W.R. 2020. African Humid Period Precipitation Sustained by Robust Vegetation, Soil, and Lake Feedbacks. Geophysical Research Letters 47(21).

Clayton J., Lonjou C. 1997. Allele and Haplotype frequencies for HLA loci in various ethnic groups. In: Charron D, ed. Genetic diversity of HLA. Functional and medical implications. Vol 1. Paris: EDK, 665- 820. https://www.amazon.fr/HLA-GeneticDiversity-Functional-Implications/dp/2842540034 
Corte-Real H.B., Macaulay V.A., Richards M.B., Hariti G., Issad M.S., CambonThomsen A., ... Sykes B.C. 1996. Genetic diversity in the Iberian Peninsula determined from mitochondrial sequence analysis. Ann Hum Genet 60(4):331-50.

Currat M., Poloni E.S., Sanchez-Mazas A. 2010. Human genetic differentiation across the Strait of Gibraltar. BMC Evol. Biol. 10: 237-243.

Degos L. \& Dausset J. 1974. Human migrations and linkage disequilibrium of HL-A system. Immunogenetics 1:195-210.

Dörk T, El-Harit E.H, Stuhrmann M, Macek Jr M, Egan M, Cutting G.R, ... Schmidtke J. 1998. Evidence for a common ethnic origin of cystic fibrosis mutation 3120+1G $\rightarrow$ A in diverse populations. American Journal of Human Genetics 63: 656-662.

Dos Santos E, Cabe A. Mc, Gonzalez-Galarza F, Jones A, Middleton D. 2016. Allele frequencies Net Database: Improvements for storage of individual genotypes and analysis of existing data. Human Immunology 77: 238-248.

Elvira M.A. 1988. El enigma Etrusco. Spain, Madrid: Historia 16, Historias del Viejo Mundo (No.11).

Escacena-Carrasco J.L. 1996. Guadalquivir salobre. Sevilla, Spain: Hidrográfica Guadalquivir.

Ferrer i Jane J. 2009. El Sistema de Numerales Iberico: Avances en su Conocimiento. Acta Paleohispanica X. Palehispanica 9: 451-479.

Gilman A. 1992. The Iberian Peninsula, 6000-1500 BC. In: Chronologies in Old World Archaeology; R.W. Ehrich, ed. Chicago, USA: Chicago University Press: vol. I 295301; vol.II 238-256.

Gomez-Casado E, del Moral P, Martinez-Laso J et al. 2000. HLA genes in Arabicspeaking Moroccans: close relatedness to Berbers and Iberians. Tissue Antigens 55: 239-49.

Gonzalez-Fortes G., Tassi E., Trucchi E., Henneberger K., Paijmans J.L.A., Diez-DelMolino D. 2019. A western route of prehistoric human migration from Africa into the Iberian Peninsula. Pro Royal Soc B.

Hajjej A, Hmida S, Kaabi H, Dridi A, Jridi A, El Gaaled A, Boukef K. 2006. HLA genes in Southern Tunisians (Ghannouch area) and their Relationship with other Mediterraneans. European Journal of Medical Genetics 49: 43-56.

Hajjej A., Almawi W.Y., Arnaiz-Villena A., Hattab L., Hmida S. 2018. The genetic heterogeneity of Arab populations as inferred from HLA genes. PLoS ONE 13(3): e0192269. 
Hammond M, du Toit E, Sanchez-Mazas A, Andrien M, Coluzzi M, de Pablo M.R, ...Migot F. 1997. HLA in sub-Saharan Africa: 12th International Histocompatibility Workshop SSAF report. In: Charron D, ed. Genetic diversity of HLA. Functional and medical implications. Vol 1. Paris: EDK, 345- 52. https://www.amazon.fr/HLAGenetic-Diversity-Functional-Implications/dp/2842540034

Herodotus. 1989. History. Madrid, Spain: Ed. Gredos.

Imanishi T, Akaza T, Kimura A, Tokunaga K, Gojobori T. 1992. Allele and haplotype frequencies for HLA and complement loci in various ethnic groups. In: Tsuji K, Aizawa M,Sasazuki T, eds. HLA 1991. England, Oxford: Oxford University Press: 1065-1220.

Izaabel H, Garchon HJ, Caillat-Zucman S et al. 1998.HLA class II DNA polymorphism in a Moroccan population from the Souss, Agadir area. Tissue Antigens 51: 106-10.

Jackes M., Lubell D., Meiklejohn C. 1997a. Healthy but mortal: human biology and the first farmers in Western Europe. Antiquity 71: 273-291.

Jackes M., Lubell D., Meiklejohn C., 1997b. On physical anthropological aspects of the Mesolithic-Neolithic transition in Iberia Peninsula. Curr. Anthrop. 38: 839-846.

Julien C.A. 1951. Historie del' Afrique du Nord: des origines a la conquete arabe. Paris, France: PAYOT.

Lalueza-Fox C. 1996. Physical anthropological aspects of the Mesolithic-Neolithic transition in Iberia Peninsula. Curr. Anthrop. 37: 689-695.

Lewthwaite J. 1986. The transition of food production: a Mediterranean perspective. In: Hunters in transition; M. Zvelebil, ed. Cambridge, England: Cambridge University Press: 53-66.

Lubell D., Sheppard P., Gilman A. 1992. The Maghreb, 20,000-4,000 BC. In: Chronologies in Old World Archaeology; R.W. Ehrich, ed. Chicago, USA: Chicago University Press: vol. I 301-308; vol. II 257-267.

Lubell D., Jackes M., Schwaroz H., et al. 1994. The Mesolithic-Neolithic transition in Portugal: isotopic and dental evidence of diet. J. Archeol. Sci. 21: 201-216.

Martínez-Laso J, De Juan D, Martínez-Quiles N, Gómez-Casado E, Cuadrado E, Arnaiz-Villena A. 1995. The contribution of the HLA-A, -B, -C and -DR, -DQ DNA typing to the study of the origins of Spaniards and Basques. Tissue Antigens 45: 23745.

Martínez-Laso J, Gazit E, Gómez-Casado E et al. 1996. HLA DR and DQ polymorphism in Ashkenazi and non-Ashkenazi Jews: comparison with other Mediterraneans. Tissue Antigens 47: 63-71. 
McCauley J.F, Schaber G.G., Breed C.S., Grolier M.J., Haynes C.V., Issawi B., ... Blom R. 1982. Subsurface Valleys and Geoarcheology of the Eastern Sahara Revealed by Shuttle Radar. Science 218 (4576): 1004-1020.

McEverdy C. \& Jones R. 1978. Atlas of World populations history. London, England: Harmondsworth Penguin Books, 99.

Medina M., Arnaiz-Villena A. 2018a. A Lunisolar Prehistoric Calendar in Lanzarote Island: "La Quesera" (Cheeseboard) from Zonzamas. In. J. Mod. Anthrop 2: 147-161.

Medina M., Arnaiz-Villena A. 2018b. The Moon: in Prehistoric Lunisolar Rock Calendar "Quesera"-Cheeseboard- at Lanzarote, Canary Islands, Spain. Int. J. Mod. Anthrop 2: 182-212.

Meiklejohn C., Schentag C.T, Venema A. 1984. Socioeconomic change and patterns of pathology and variations in the Mesolithic and Neolithic in Western Europe: some suggestions. In: Paleopathology at the origins of agriculture; M-N Cohen and J.G Armelagos, eds. Orlando, Florida: Academic Press, 75-100.

Nei M. 1972. Genetic distances between populations. Am. Nat. 106: 283.

Nei M. 1973. Analysis of the gene diversity in subdivided populations. PNAS 70: 33213323.

Nei M, Tajima F, Tateno Y. 1983. Accuracy of estimated phylogenetic tresfrom molecular data II. Gene frequency data. J. Mol. Evol. 19: 153-170.

Orduña-Aznar E. 2005. Sobre algunos posibles numerales en textos ibéricos. Paleohispnaica IX. Paleohispanica. 5: 491-506.

Orduña-Aznar E. 2013. Los Numerales Ibéricos y el Vascoiberismo. Acta Paleohispánica XI. Paleohispanica. 13: 517-529.

Padoa C, Goldman A, Jenkins T, Ramsay M. 1999. Cystic fibrosis carrier frequencies in populations of African origin. Journal of Medical Genetics 36: 41-44.

Papassavas E, Spyropoulou-Vlachou M, Papassavas A, Schipper R, Doxiadis I, Stavropoulos-Giokas C. 2000. MHC Class I and Class II Phenotype, Gene, and Haplotype Frequencies in Greeks Using Molecular Typing Data. Human Immunology 61: 615-623.

Rachid R.A. 1994. Imazighen del Maghreb entre oriente y occidente (introducción a los Bereberes). Granada, Spain: La Gioconda.

Regueiro J.R, Arnaiz-Villena A. 1988. Human MHC class III (Bf, C2, C4) genes and GLO: their association with other HLA antigens and extended haplotypes in the Spanish population. Tissue Antigens 31 (1): 14-25. 
Rodriguez-Córdoba S, Bootello A, Arnaiz-Villena A. 1981. Bf polymorphism and its relationship with HLA antigens in a sample of the Spanish Population: high BfF1 frequencies. Tissue Antigens 17(2):231-7.

Roitberg-Tambur A, Witt CS, Friedmann A et al. 1995. Comparative analysis of HLA polymorphism at the serologic and molecular level in Moroccan and Ashkenazi Jews. Tissue Antigens 46: 104-10.

Ruhlen M. 1991. A guide to the World's Languages, v. 1, Classification. London, England: D. Arnold.

Saitou N., Nei M. 1987. The neighbor-joining method: a new method for reconstructing phylogenetic trees. Mol. Biol. Evol. 4: 406-425.

Sellier J, Sellier A. 1993. Atlas des Peuples d'Orient.France, Paris: Editions La Découverte.

Stavropoulos-Giokas C., Papasteriades C., Polymenidis A., Naumova E., Saruhan G., Varnavidou A. 1997. HLA in MEDI Region Populations: 12th International Histocompatibility Workshop MEDI Region Report. In: Charron D., (ed.) Genetic Diversity of HLA: Functional and Medical Implications, Paris: EDK, 1997, pp. 323334.

https://www.amazon.fr/HLA-Genetic-Diversity-Functional-

Implications/dp/2842540034

Young F.W., Bann C.M. 1996. Visual Statistics System. In: Stine R.A, Fox J. (eds.); Statistical computing environments for social researchers. New York: Sage Publications; 207-236.

To cite this article:

Arnaiz-Villena A., Juarez I., Palacio-Grüber J., Lopez-Nares A., Suarez-Trujillo F. 2021. The Northern Migrations from a drying Sahara (6,000 years BP): cultural and genetic influence in Greeks, Iberians and other Mediterraneans

International Journal of Modern Anthropology. 2 (15): 484 - 507

DOI: http://dx.doi.org/10.4314/ijma.v2i15.5

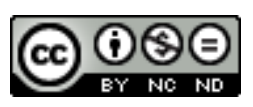

This article, as all articles published in this journal, is under The Creative Commons Attribution:

Attribution-NonCommercial-NoDerivatives 4.0 International (CC BY-NC-ND 4.0).

https://creativecommons.org/licenses/by-nc-nd/4.0/ 